\title{
Public Pensions
}


This page intentionally left blank 


\section{Public Pensions \\ Gender and Civic Service in the \\ States, I850-1937}

Susan M. Sterett

CORNELL UNIVERSITY PRESS

Ithaca and London 
Copyright $(\mathcal{2} 2003$ by Cornell University

All rights reserved. Except for brief quotations in a review, this book, or parts thereof, must not be reproduced in any form without permission in writing from the publisher. For information, address Cornell University Press, Sage House, 512 East State Street, Ithaca, New York 14850.

First published 2003 by Cornell University Press

Printed in the United States of America

Library of Congress Cataloging-in-Publication Data

Sterett, Susan Marie.

Public pensions : gender and civic service in the states, 1850-1937 I Susan M. Sterett.

p. $\mathrm{cm}$.

Includes bibliographical references and index.

ISBN o-80I4-3984-I (cloth : alk. paper)

r. State governments-Officials and employees-Pensions-United

States-History. 2. Local officials and employees-Pensions-United

States-History. I. Title.

$\mathrm{JK}_{2474 . S_{74} 2003}$

$331.25^{\prime} 29135173^{\prime} 09034-\mathrm{de21}$

2003002040

Cornell University Press strives to use environmentally responsible suppliers and materials to the fullest extent possible in the publishing of its books. Such materials include vegetable-based, low-VOC inks and acid-free papers that are recycled, totally chlorine-free, or partly composed of nonwood fibers. For further information, visit our website at www.cornellpress.cornell.edu.

Cloth printing Io 987654321 
For Maya who thinks writing about firefighters and mothers is cool-wow 
This page intentionally left blank 